\title{
TR81 DÜZEY 2 BÖLGESI ORMAN ÜRÜNLERI ENDÜSTRISINDE KARO MODELI İLE REKABET ANALIZi
}

\author{
Selman KARAYILMAZLAR ${ }^{1}$, Gülay ŞENER UZCAN ${ }^{2, *}$ \\ ${ }^{1}$ Bartın Üniversitesi, Orman Fakültesi, Orman Endüstri Mühendisliği Bölümü, 74100, Bartın, Türkiye \\ ${ }^{2}$ Bartın Üniversitesi, Meslek Yüksekokulu, Yönetim ve Organizasyon Bölümü, 74100, Bartın, Türkiye \\ gsener@bartin.edu.tr, selman@bartin.edu.tr
}

\section{ÖZET}

Küreselleşme ile ivme kazanan bilgi ve iletişim teknolojilerindeki gelişmeler, ekonomilerin iş yapma biçimlerini ve politikalarını önemli ölçüde etkilemiştir. Yenilikçi, bilgiye dayalı ve yüksek katma değerli üretim ve pazarlama stratejilerine geçebilenler küresel rekabette önemli aktörler olabilecektir. Rekabet ilişkileri ülke, bölge ve işletme düzeyinde incelenmektedir. Ancak rekabet gücünün oluşmasında rol oynayan rekabet ilişkilerini en iyi açıklayan ölçek bölgesel endüstriler düzeyinde olanıdır. Çünkü rekabet gücü söz konusu olduğunda, belli bölgelerde başarılı olmuş sektörler karşımıza çıkmakta ve bölgeye özel koşullar başarıyı getirmektedir. Bu amaçla TR81 Düzey 2 Bölgesi Orman Ürünleri Endüstrisi iş kümelenmesinin rekabet gücü Michael Porter'ın karo modeline göre analiz edilmiştir. Uygulamada veri toplamak amacı ile tam sayım tekniği kullanılarak Zonguldak, Karabük ve Bartın illerinde belirlenen 65 adet orman ürünleri endüstri işletmesine anket uygulanmıştır. İş kümelenmesi rekabet analizi ile kümelenmenin rekabetçi avantajları ve dezavantajları üzerinde saptamalarda bulunulmuş, kümelenmeyi geliştirmek ve rekabet gücünü artırabilmek için eksiklerin neler olduğu, neler yapılabileceği sonuç ve önerilerde ifade edilmiştir. Bu çalışmanın, "TR81 bölgesi mobilya ve kereste sektörünün" rekabetçiliğini geliştirmek için yapılacak çalışmalara ve bölgesel planlara katkı sunacağı öngörülmüştür.

Anahtar Kelimeler; Rekabet, Rekabet Gücü, Rekabet Analizi, Karo Modeli, TR81 Düzey 2 Bölgesi.

\section{COMPETITIVE ANALYSIS WITH DIAMOND MODEL IN TR81 NUTS 2 REGION FOREST PRODUCTS INDUSTRY}

\begin{abstract}
Developments in information and communication technologies gaining momentum with globalization have influenced economies' business manners and policies significantly. The economies which are able to transform into innovative, information-based and value-added production structure and marketing strategies can be important business actors that are competing in global market. Competitive relationships have been studied at the level of country, region and business. The ideal scale that explains competitive relationships which play an important role in constituting competitive advantage is at the level of regional industries. For this reason, when competitive advantage is considered, we encounter with sectors that have been successful in certain regions and site-specific conditions bring success. Accordingly, TR81 NUTS 2 Region Forest Products Industry business cluster's competitive advantage has been analyzed with the help of Michael Porter's diamond model. In order to collect data, complete inventory method has been used by applying surveys to 65 forest product businesses that were specified in the cities Zonguldak, Karabuk, and Bartın.
\end{abstract}


With the business cluster competitive analysis, cluster's competitive advantages and disadvantages have been addressed. In addition, shortcomings and possible solutions to develop the cluster and to increase its competitive advantage have been stated in the sections of conclusion and suggestions. It is estimated that this study can make a significant contribution to studies and regional projections to develop competitiveness of "TR81 region furniture and wood sector".

Key words: Competition, Competitive Advantage, Competitive Analysis, Diamond Model, TR81 NUTS 2 Region.

\section{GiRiş}

Rekabet, evrensel kurallara bağlı bir ilişkiler sistemi olarak, doğa bilimlerinde olduğu gibi, kıt kaynakları kullanarak sınırlı bir talebi ekonomik olarak karşılama ve varlığını geliştirerek sürdürebilme yeteneğini kazanmaktır. Bu bağlamda rekabet çok farklı amaçlarla farklı unsurlar vurgulanarak tanımlanabilen; iktisadi, siyasi ve sosyal boyutları olan bir kavramdır (URL-1).

Sarıdoğan (2010) rekabet gücünü, "bir iktisadi birimin (birey, firma, endüstri, ülke, bölge), veri başlangıç koşullarına göre, belirlenen amaçlara ulaşma süreci ve sonucundaki hedef göstergeler açısından rakiplerine göre üstünlüğe sahip olmasıdır” şeklinde tanımlamıştır.

Dünya Ekonomik Forumu (Word Economic Forum) rekabet gücünü, bir ülkenin ürettiği mal ve hizmetlerin dünya pazarlarındaki payı olarak değil, o ülkede sürdürülebilir büyümeyi sağlayacak olan kurumların, politikaların ve üretim faktörlerinin tümünü kapsayan verimlilik düzeyi olarak tanımlanmaktadır (Word Economic Forum, 2014).

Bölgesel rekabet gücü kavramı, bölgelerin bir yandan dış rekabet koşulları içerisinde uluslararası pazarlara yönelik mal ve hizmet üretebilmeleri bir yandan da bölge içi yüksek ve sürdürülebilir gelir seviyeleri yaratabilmeleri, ayrıca istihdam olanakları sağlayabilmeleri olarak ifade edilebilir (URAK, 2011).

Görüldüğü gibi rekabet gücü ulusal düzeyde, bölgesel düzeyde ve işletme düzeyinde tanımlanabilmektedir. Ancak rekabet ilişkilerinin en iyi incelenebildiği, açıklanabildiği ölçek, bölgesel endüstriler düzeyinde olandır. Bölgesel bir piyasadaki işletmenin rekabet gücü aynı piyasa veya bölgedeki rakipleri ile kıyaslanabilirken, bir endüstrinin rekabet gücü ticaretin söz konusu olduğu diğer bölge veya ülkelerdeki endüstrilerle karşılaştırılabilmektedir. Bu nedenle rekabet gücü olan bir endüstri, bölgesel düzeyde veya uluslararası düzeyde rekabet gücü olan işletmelere sahip endüstri olarak ifade edilebilmektedir (McFetridge, 1995). Bu doğrultuda aslında endüstri bölgelerinden ve onların rekabet güçlerinden bahsedilmektedir.

Porter’a (1998) göre de rekabet gücü incelenirken, işletme ve sektörel rekabet üzerinde odaklanılmalıdır. Çivi (2001) Porter'ın konuya yaklaşımını; ülkelerin rekabet gücünü, mevcut kaynaklarını en etkin kullanarak elde edebileceği, bunun için de her ülkenin uzmanlaşabileceği alanlar seçmesi ve kurulacak endüstri kümeleriyle de sinerji etkisi yaratması gerektiği şeklinde özetlemiştir. Porter (1990) “Ulusların Rekabet Üstünlüğü” adlı kitabında, bölgesel rekabet gücünün yaratılmasını etkileyen faktörleri tanımlamış ve geliştirmiş olduğu etkileşimsel modeli "karo modeli" olarak kavramsallaştırmıştır. Çalışmanın da yöntemine temel oluşturan bu dört unsur; faktör şartları, talep şartları, ilgili ve destekleyici kuruluşlar ve firma stratejileri rekabet ortamıdır.

Faktör koşulları; firmaların yeri, insan sermayesi, sermaye kaynakları, fiziksel altyapı, bilgi altyapısı ve sosyal olanaklar gibi sanayilerin rekabet gücünün gelişmesinde rol oynayan üretim faktörlerindeki durumunu kapsamaktadır (Bulu vd., 2004). Talep koşulları; toplam talep büyüklüğünü, onun artış hızını, talebin farklı ürün grupları arasındaki dağılımını, müşterilerin özelliklerini ve sayısını tanımlamaktadır. İlgili ve destekleyici kuruluşlar; işletmelerin faaliyet gösterdiği üretim alanını destekleyen gelişmiş işletmelerin ve kurumların olmasını ifade etmektedir (Cansız, 2011). İşletme stratejisi ve rekabet yapısı; işletmelerin nasıl yaratıldı̆̆ını, örgütlendiğini ve yönetildiğini belirleyen koşullar ile bulunulan bölgenin rekabet yapısını anlatır (Keskin, 2009).

Bölgelerin rekabet gücü, karo modelindeki unsurların doğru etkileşimleri sonucunda oluşabilmektedir. Karo modelindeki her bir unsur diğer unsurlarla karşılıklı bağımlılık ilişkileri geliştirir veya geliştiremez. Unsurların güçlenmesi ve birbirlerini etkilemesi karonun iyi işleyen bir sisteme dönüşmesinde temel olandır. Alsaç’a (2010) göre rekabet gücünün oluşmasının başlangıç aşamasında karo modelindeki unsurların tamamı ihtiyaç duyulan düzeyi sağlamasa da zaman içerisinde karşılıklı etkileşim ile modeldeki unsurlar gelişmektedir. 
Çalışmada bölge ve sektör ölçeğinde, TR81 bölgesi ve orman ürünleri endüstri sektörü seçilmiștir. Orman ürünleri endüstrisi, literatürde mobilya, ağaç-orman ürünleri ve kâğıt olarak sınıflandırılmaktadır. Bölgenin koşulları dikkate alındığında mobilya ve ağaç-orman (kereste) ürünleri grubu çalışmayı oluşturmuştur. TR81 bölgesinin kalkınması ve rekabet avantajının artırılması için tüm planlamalar ve uygulamalar TR81 Düzey 2 Bölgesi bütünlüğünde ve BAKKA (Batı Karadeniz Kalkınma Ajansı) koordinasyonunda gerçekleştirilmektedir.

TR81 Düzey 2 Bölgesi ağaç-orman ürünleri ve mobilya sektörü hem orman kaynaklı hammadde avantajı hem de geçmişten gelen meslek bilgisi avantajıyla bölge için verimli ve etkin bir sektör olma potansiyeline sahiptir. Diğer taraftan bölgede ki sanayi faaliyetleri madencilik ve demirçelik sektörlerine bağımlıdır. Bu nedenle bölgedeki sektörel çeşitliliği sağlamak ve mevcut sanayi faaliyetlerinin rekabet gücünü artırmak bölge planlarında öncelikli amaç olmaktadır (BAKKA, 2013a; 2013b; 2014; 2015). BAKKA tarafından hazırlanan bölge planları, daha üst ölçekte Onuncu Kalkınma Planı (Kalkınma Bakanlığı, 2013) ve Bölgesel Gelişme ve Ulusal Strateji Belgesi (Kalkınma Bakanlığı, 2014) dikkate alınarak ulusal stratejilerle bağlantılı kurgulanmıştır. Bu planlar doğrultusunda TR81 Düzey 2 Bölgesi Orman Ürünleri Endüstrisinin rekabet gücünü değerlendirmek önemli görülmüştür.

Çalışmada, söz konusu karo modeli doğrultusunda, TR81 Düzey 2 Bölgesi Orman Ürünleri Endüstrisi iş kümelenmesinin rekabet gücü analiz edilmiştir. Bu çalışmanın, "TR81 bölgesi mobilya ve kereste sektörünün" rekabetçiliğini geliştirmek için yapılacak çalışmalara ve bölgesel planlara katkı sunacağı öngörülmektedir.

\section{MATERYAL VE YÖNTEM}

\subsection{Araştırmanın Yöntemi ve Evreni}

Çalışmada "TR81 Düzey 2 Bölgesi Orman Ürünleri Endüstrisi" iş kümelenmesi analizini gerçekleştirebilmek için Porter'ın karo modeli yöntem olarak seçilmiştir. Yöntemdeki karo modeline temel oluşturan dört unsur; faktör şartları, talep şartları, ilgili-destekleyici kuruluşlar ve firma stratejileri-rekabet ortamıdır. Bölgelerin rekabet gücü, karo modelindeki unsurların doğru etkileşimleri sonucunda oluşabilmektedir. Unsurların güçlenmesi ve birbirlerini etkilemesi karonun iyi işleyen bir sisteme dönüşmesini sağlamaktadır.

Sahada veri toplamak için yüz yüze anket yöntemi kullanılmış ve anket formu "TR81 Düzey 2 Bölgesinin Rekabetçiliğini Ölçen Anket" başlığında yapılandırılmıştır. Anket soruları oluşturulurken Dünya Ekonomik Formunun her yıl hazırladığı Küresel Rekabet Raporu (2015) çalışmasında kullanılan anket çalışmalarından ve Arıç'ın (2011) yayımlanmamış doktora tezinde kullandığı anket formundan yararlanılmıştır. Anket 4 bölümden ve 44 sorudan oluşmaktadır ve anket soruları Tablo 1, Tablo 2, Tablo 3 ve Tablo 4'de belirtildiği gibidir. Rekabet gücü anketinde ki sorular beşli Likert ölçeğine göre oluşturulmuştur.

Çalışmada TR81 bölgesi ve orman ürünleri endüstri sektörü seçilmiştir. Orman ürünleri endüstrisi, literatürde mobilya, ağaç-orman ürünleri ve kâğıt olarak sınıflandırılmaktadır. TR81 bölgesinde ancak iki kâğıt işletmesi olduğu, birisinin ise anket görüşmesini kabul etmemesi, ayrıca bölge planlarındaki önceliklendirme nedeniyle mobilya ve ağaç-orman ürünleri (kereste) grubu çalışmayı oluşturmuştur.

İşletmelerin seçimi için TR81 Düzey 2 Bölgesinde, Organize Sanayi Bölgeleri ve Ticaret ve Sanayi Odaları olan yerleşim yerleri temel alınmıştır. Bu doğrultuda Zonguldak için Ereğli ve Çaycuma Ticaret ve Sanayi Odalarından, Karabük için Ticaret ve Sanayi Odasından, Bartın için Ticaret ve Sanayi Odasından NACE kodları 16 ve 31 olmak üzere işletme listeleri oluşturulmuştur. NACE Rev. 2 istatistiki sınıflama sisteminde; 16 kodu ağaç, ağaç ürünleri ve mantar ürünleri imalatını, 31 kodu mobilya sektörü ve alt sektörlerini ifade eder. Temel ölçüt Organize Sanayi Bölgesi olan yerleşim yerleri olmasına rağmen, Organize Sanayi Bölgesi olmayan ancak Ticaret ve Sanayi odasına sahip olan, Devrek’teki işletmelerin sayısı ve kalitesi bu bölgedeki işletmeleri de Zonguldak'a bağlı olarak çalışma listesine eklenmesini gerekli kılmıştır. Ticaret ve Sanayi Odalarına kayıtlı 16 ve 31 NACE kodlarına ve organize sanayi bölgesi olan yerleşim yerlerine göre oluşturulan listedeki işletmelerin bütünü çalışmaya dâhil edilmiştir ve tam sayım tekniği kullanılmıştır. Toplam 111 işletmeden 65 tanesine ulaşılmıştır. Sonuçlar iller ve sektörler bazında ortalama değerleri alınarak değerlendirilmiştir. Daha sonra rekabet gücü anketi değerlendirmelerinden elde edilen bilgiler kullanılarak Porter'ın "Karo" modeli ile bölgenin rekabet gücü analiz edilmiştir. 


\section{BULGULAR}

\subsection{Faktör Şartları}

Anket çalışması sonucunda TR81 Düzey 2 Bölgesi mobilya ve kereste işletmelerinin faktör şartları illere ve sektöre göre Tablo 1'de gösterilmiştir.

Tablo 1: TR81 Düzey 2 Bölgesi Orman Endüstri İşletmelerinin faktör şartları.

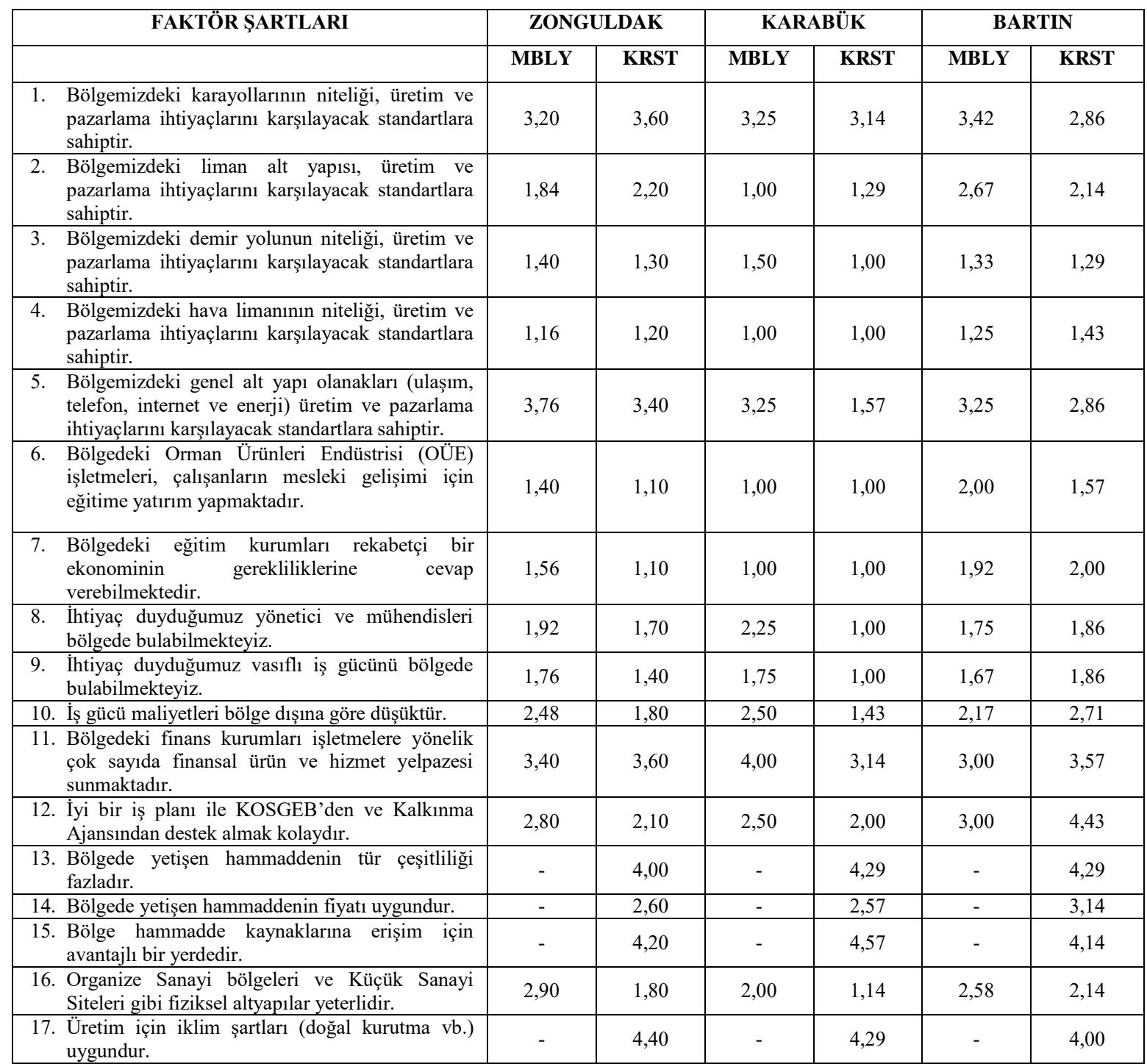

Tablo 1'e göre avantajlar:

- Bölgede yetişen hammadde kaynaklarına erişim ve hammaddenin çeşitliliği kereste işletmeleri açısından üç ilde de en önemli avantaj olarak görülmektedir. En yüksek değerler 4'ün üzerindeki ortalama ile hammadde faktörüne aittir.

- Bölgedeki finans kurumlarının işletmelere yönelik çok sayıda finansal ürün ve hizmet yelpazesi sunabilmeleri üç ilde de hem mobilya hem de kereste işletmeleri için bir avantaj olarak görülmektedir.

- Bölgedeki karayollarının niteliğinin, üretim ve pazarlama ihtiyaçlarını karşılayacak standartlara sahip olmasını üç ilde de mobilya işletmeleri bir avantaj olarak görmektedir. Ancak Bartın'da yer alan kereste işletmeleri 2.86 ortalama değere sahiptir. Çünkü kereste işletmelerinin bazılarının ormanlık alanda, ulaşımı daha zor yerleşkelerde olduğu görülmektedir.

- Bölgedeki genel alt yapı olanaklarının (telefon, internet ve enerji) üretim ve pazarlama ihtiyaçlarını karşlayacak standartlara sahip olmasını üç ilde de mobilya işletmeleri bir avantaj olarak görmektedir. Kereste de ise Zonguldak işletmeleri 3.40 değerle bir avantaj olarak görmekte, ancak Karabük işletmeleri 1.57 değerle ve Bartın işletmeleri ise 2.86 değerle mevcut durumu yeterli görmemektedir. Özellikle Karabük kereste işletmeleri haftada birkaç defa tekrarlayan elektrik kesintilerinden ve internet hatlarındaki sorunlardan bahsetmektedirler. 
- İyi bir iş planı ile KOSGEB'den ve Kalkınma Ajansından destek almanın kolay olduğunu düşünen il ise sadece Bartın olmuştur. Mobilya işletmeleri 3.00, kereste işletmeleri ise 4.43 ortalama değere sahiptir. Bartın bölgesindeki kereste işletmelerinin daha yenilikçi ve gelişmeye istekli olduklarını söyleyebiliriz.

Tablo 1'e göre dezavantajlar:

- Bölgedeki liman alt yapısının, demir yolunun ve hava limanının niteliğinin üretim ve pazarlama ihtiyaçlarını karşılayacak standartlara yeterince sahip olmadığı, her üç ildeki mobilya ve kereste işletmeleri tarafından düşünülmektedir.

- Bölgedeki Orman Ürünleri Endüstrisi (OÜE) işletmelerinin çalışanların mesleki gelişimi için eğitime yatırım yapmadığ1, her üç ildeki mobilya ve kereste işletmeleri tarafından düşünülmektedir. Değerler çok düşük 1'e yakın değerlerdir. Üç il içinde en düşük ortalama 1 değerine sahip Karabük'tür.

- Bölgedeki eğitim kurumlarının rekabetçi bir ekonominin gerekliliklerine cevap veremediği, her üç ildeki mobilya ve kereste işletmeleri tarafından düşünülmektedir. Yine üç il içinde en düşük ortalama 1 değerine sahip Karabük'tür.

- İhtiyaç duyduğu vasıflı iş gücünü ,yönetici ve mühendisleri bölgede bulamadığı, her üç ildeki mobilya ve kereste işletmeleri tarafından düşünülmektedir. Ayrıca iş gücü maliyetlerinin de bölge dışına göre daha düşük olmadığı, her üç ildeki mobilya ve kereste işletmeleri tarafindan düşünülmektedir.

- İyi bir iş planı ile KOSGEB'den ve Kalkınma Ajansından destek almanın kolay olmadığı, Zonguldak ve Karabük işletmeleri tarafından düşünülmektedir. Bartın ilinin ise diğer iki ilden farklı olarak, İyi bir iş planı ile KOSGEB'den ve Kalkınma Ajansından destek almanın kolay olduğunu düşünmektedir ve mobilya işletmeleri 3.00, kereste işletmeleri 4.43 gibi yüksek bir ortalama değere sahiptir.

- Organize Sanayi bölgeleri ve Küçük Sanayi Siteleri gibi fiziksel altyapıların yeterli olmadığı, her üç ildeki mobilya ve kereste işletmeleri tarafından düşünülmektedir.

\subsection{Talep Şartları}

Anket çalışması sonucunda TR81 Düzey 2 Bölgesi mobilya ve kereste işletmelerinin talep şartları illere ve sektöre göre Tablo 2'de gösterilmiştir.

Tablo 2: TR81 Düzey 2 Bölgesi Orman Endüstri İşletmelerinin talep koşulları.

\begin{tabular}{|c|c|c|c|c|c|c|}
\hline \multirow[t]{2}{*}{ TALEP KOŞULLARI } & \multicolumn{2}{|c|}{ ZONGULDAK } & \multicolumn{2}{|c|}{ KARABÜK } & \multicolumn{2}{|c|}{ BARTIN } \\
\hline & MBLY & KRST & MBLY & KRST & MBLY & KRST \\
\hline $\begin{array}{l}\text { 18. Bölgede işletmemizin devamlılığını sağlayacak talep } \\
\text { mevcuttur. }\end{array}$ & 3,68 & 2,50 & 4,25 & 3,14 & 3,25 & 3,29 \\
\hline 19. Ürünlerimize bölge dışından da talep gelmektedir. & 3,60 & 4,40 & 3,50 & 4,43 & 3,83 & 4,43 \\
\hline $\begin{array}{l}\text { 20. İşletmemiz açısından tüketicilerin beklentileri, yeni } \\
\text { ürünler geliştirilmesi üzerinde etkilidir. }\end{array}$ & 4,04 & 2,20 & 4,50 & 2,86 & 3,58 & 3,71 \\
\hline $\begin{array}{l}\text { 21. Bölgedeki tüketicilerin, ürünlerin alımı ile ilgili } \\
\text { kararlarında en önemli etken ürünün düşük fiyatlı } \\
\text { olmasıdır. }\end{array}$ & 3,44 & 3,00 & 4,00 & 3,71 & 3,08 & 3,43 \\
\hline $\begin{array}{l}\text { 22. Bölgedeki tüketicilerin, ürünlerin alımı ile ilgili } \\
\text { kararlarında en önemli etken ürünün nitelikli } \\
\text { olmasıdır. }\end{array}$ & 3,56 & 3,80 & 3,75 & 4,43 & 3,42 & 3,00 \\
\hline $\begin{array}{l}\text { 23. Bölgedeki Orman Ürünleri Endüstri işletmeleri } \\
\text { ağırlıklı olarak iç pazara yönelik üretim yapmaktadır, } \\
\text { ihracatı ihmal etmektedir. }\end{array}$ & 3,16 & 2,50 & 2,75 & 1,00 & 3,58 & 4,29 \\
\hline
\end{tabular}

TR81 Düzey 2 Bölgesi Orman Endüstri İşletmelerinin talep koşulları tablosu incelendiğinde, anket sorularına verilen yanıtların iller ve sektörler bakımından farklılıklar gösterdiği ve karşılaştırmalı değerlendirmeler yapılması gerekliliği ortaya çıkmıştır. Bu nedenle avantajlar ve dezavantajlar birlikte değerlendirilecektir.

Tablo 2'ye göre avantajlar ve dezavantajlar:

- Her üç ilde mobilya işletmeleri "bölgedeki işletmelerin devamlılığını sağlayacak iç talebin mevcut olduğunu" ifade etmişlerdir. Benzer bir şekilde her üç ilde mobilya ve kereste işletmeleri "ürünlere bölge dışından da talep geldiğini” söylemişlerdir.

- Her üç ilde ki mobilya işletmeleri "işletmeleri açısından tüketicilerin beklentilerinin, yeni ürünler geliştirilmesi üzerinde etkili olduğunu” düşünmektedir. Zonguldak’ta yer alan mobilya işletmeleri 4.04, Karabük'te yer alan mobilya işletmeleri 4.50, Bartın'da yer alan mobilya işletmeleri 3.58 ortalama değere sahiptir. Ortalama değerler oldukça iyi düzeydedir. Kereste işletmelerinde ise Zonguldak 2.20 değer ve Karabük'ün 2.86'lık değer ile bu konuda olumlu düşündüğü söylenemez. Ancak “iyi bir iş 
planı ile KOSGEB'den ve Kalkınma Ajansından destek almanın kolay olduğunu” düşünmesinde de olduğu gibi, Bartın kereste işletmeleri 3.71'lik değer ile bu konuda, diğerlerinden farklı olarak olumlu düşünmüştür.

- Her üç ilde ki mobilya ve kereste işletmeleri "bölgedeki tüketicilerin, ürünlerin alımı ile ilgili kararlarında en önemli etkenin hem ürünün düşük fiyatlı olması hem de ürünün nitelikli olması olduğunu" düşünmektedir.

- Her iki ilde ki mobilya işletmeleri "bölgedeki Orman Ürünleri Endüstri işletmelerinin ağırlıklı olarak iç pazara yönelik üretim yaptığını, ihracatı ihmal ettiğini” düşünmektedir.

\section{3 İlgili ve Destekleyici Kuruluşlar}

Anket çalışması sonucunda TR81 Düzey 2 Bölgesi mobilya ve kereste işletmelerinin ilgili ve destekleyici kuruluş şartları illere ve sektöre göre Tablo 3'de gösterilmiştir.

Tablo 3: : TR81 Düzey 2 Bölgesi Orman Endüstri İşletmelerinin ilgili ve destekleyici kuruluşların şartları.

\begin{tabular}{|c|c|c|c|c|c|c|}
\hline \multirow{2}{*}{$\begin{array}{l}\text { İLGİLI VE DESTEKLEYİĊ } \\
\text { KURULUŞLAR }\end{array}$} & \multicolumn{2}{|c|}{ ZONGULDAK } & \multicolumn{2}{|c|}{ KARABÜK } & \multicolumn{2}{|c|}{ BARTIN } \\
\hline & MBLY & KRST & MBLY & KRST & MBLY & KRST \\
\hline $\begin{array}{l}\text { 24. İşletmemizin üretimine dönük çok sayıda } \\
\text { tedarikçi vardır. }\end{array}$ & 4,08 & 4,50 & 3,00 & 4,14 & 3,33 & 4,43 \\
\hline $\begin{array}{l}\text { 25. Bölgedeki tedarikçi firmalar kaliteli hizmet } \\
\text { vermektedir. }\end{array}$ & 3,36 & 3,00 & 3,75 & 3,29 & 3,00 & 2,86 \\
\hline $\begin{array}{l}\text { 26. Üretimde kullandığımız girdilerin temininde } \\
\text { bölgesel tedarikçileri tercih etmekteyiz. }\end{array}$ & 3,72 & 3,80 & 4,25 & 4,29 & 3,25 & 4,14 \\
\hline $\begin{array}{l}\text { 27. Bölgedeki tedarikçi işletmeler işletmemizin } \\
\text { rekabet gücünün artmasına katkı } \\
\text { sağlamaktadır. }\end{array}$ & 2,92 & 2,60 & 3,00 & 2,86 & 2,58 & 3,57 \\
\hline $\begin{array}{l}\text { 28. Sektördeki işletmeler, tanıtım, pazarlama, } \\
\text { nakliye ve AR_GE gibi alanlarda işbirliği } \\
\text { yapmaktadır. }\end{array}$ & 1,20 & 1,10 & 1,00 & 1,00 & 1,92 & 2,14 \\
\hline $\begin{array}{l}\text { 29. Ürünlerimizin dağıtım ve pazarlamasında } \\
\text { yerel şirketler kullanılmaktadır. }\end{array}$ & 1,48 & 1,00 & 1,00 & 2,29 & 2,33 & 2,29 \\
\hline $\begin{array}{l}\text { 30. Yereldeki Orman Fakülteleri ile olan } \\
\text { ilişkilerimiz, üretim süreçlerimiz ve } \\
\text { pazarlama stratejilerimiz üzerinde etkili } \\
\text { olmaktadır. }\end{array}$ & 1,32 & 1,00 & 1,00 & 1,00 & 2,08 & 2,14 \\
\hline $\begin{array}{l}\text { 31. Bölgede ağaç atıklarını kullanan fabrikalar } \\
\text { mevcuttur. }\end{array}$ & 1,44 & 1,30 & 1,00 & 1,00 & 1,58 & 2,29 \\
\hline $\begin{array}{l}\text { 32. Bölgedeki KOSGEB ve Kalkınma Ajansının } \\
\text { çalışmaları işletmemizin rekabet gücünün } \\
\text { artmasına katkıda bulunmaktadır. }\end{array}$ & 2,64 & 2,00 & 2,50 & 1,71 & 3,08 & 3,71 \\
\hline $\begin{array}{l}\text { 33. Ticaret ve Sanayi Odaları, Meslek Odaları } \\
\text { gibi kuruluşların çalışmaları işletmemizin } \\
\text { gelişmesine ve sektördeki ilişkilerin } \\
\text { artmasına katkıda bulunur. }\end{array}$ & 1,83 & 1,70 & 2,25 & 1,86 & 3,08 & 4,00 \\
\hline
\end{tabular}

Tablo 3'e göre avantajlar:

- İşletmelerinin üretimine dönük çok sayıda tedarikçi olduğu ve tedarikçi firmaların kaliteli hizmet verdiği her üç ildeki mobilya ve kereste işletmeleri tarafından düşünülmektedir.

- Her üç ildeki mobilya ve kereste işletmeleri, üretimde kullanılan girdilerin temininde ağırlıklı olarak bölgesel tedarikçileri tercih etmektedir. Özellikle kereste işletmelerinin, tablodaki en yüksek değere, 4 ortalamaya sahip olduğu görülmüştür.

- Bölgedeki mobilya ve kereste işletmeleri çok sayıda tedarikçi olduğunu, kaliteli hizmet verdiklerini düşünseler de bu işletmelerin onların rekabet gücünün artmasına etkisini yeterli bulmamaktadırlar.

- Ticaret ve Sanayi Odaları, Meslek Odaları gibi kuruluşların çalışmalarının işletmelerinin gelişmesine ve sektördeki ilişkilerin artmasına katkıda bulunduğunu, sadece Bartın mobilya ve kereste işletmeleri düşünmektedir. Mobilya işletmeleri 3.08, kereste işletmeleri 4.00 ortalama değere sahiptir.

- Bölgedeki KOSGEB ve Kalkınma Ajansının çalışmalarının işletmelerin rekabet gücünün artmasına katkıda bulunduğunu da, sadece Bartın mobilya ve kereste işletmeleri düşünmektedir. Mobilya işletmeleri 3.08, kereste işletmeleri 3.71 ortalama değere sahiptir.

Tablo 3'e göre dezavantajlar:

- Yereldeki Orman Fakülteleri ile olan ilişkilerin, üretim süreçleri ve pazarlama stratejileri üzerinde etkili olmadığı, her üç ildeki mobilya ve kereste işletmeleri tarafından düşünülmektedir. Ancak ortalama 
Zonguldak ve Karabük’te çok daha düşüktür ve 1 değerine sahiptir. Bartın'da ise mobilya işletmeler 2,08 değere, kereste işletmeleri ise 2,14 değerine sahip olduğu görülmüştür.

- Sektördeki işletmelerin tanıtım, pazarlama, nakliye ve AR_GE gibi alanlarda işbirliği yapmadığı, her üç ildeki mobilya ve kereste işletmeleri tarafından düşünülmektedir.

- Her üç ildeki mobilya ve kereste işletmelerinin, ürünlerin dağıtım ve pazarlamasında yerel şirketleri kullanmadığı görülmektedir.

- Bölgedeki KOSGEB ve Kalkınma Ajansının çalışmalarının işletmelerinin rekabet gücünün artmasına katkıda bulunmadığı, Zonguldak ve Karabük illeri mobilya ve kereste işletmeleri tarafindan düşünülmektedir. Bartın ili mobilya işletmeleri 3,08'lik ortalama değer ve kereste işletmeleri de 3,71'li ortalama değer ile bu konu hakkında olumlu düşünmüştür.

- Ticaret ve Sanayi Odaları, Meslek Odaları gibi kuruluşların çalışmalarının işletmelerinin gelişmesine ve sektördeki ilişkilerin artmasına katkıda bulunmadığı, Zonguldak ve Karabük illeri mobilya ve kereste işletmeleri tarafından düşünülmektedir. Bartın ili ise KOSGEB ve Kalkınma Ajansında da olduğu gibi mobilya işletmeleri 3,08'lik ortalama değer ve kereste işletmeleri de 4'lük ortalama değer ile bu konu hakkında olumlu düşünmektedir.

- Bölgede ağaç atıklarını kullanan fabrikaların mevcut olmadığı, her üç ildeki mobilya ve kereste işletmeleri tarafından düşünülmektedir. Ancak Resan Vadi isimli bir işletme ağaç atıklarını kullanarak yakıt için ürün üretmeye başlamıştır. Ancak henüz çevresindeki işletmelerle yeterli ilişkiyi kuramamıştır.

\section{4 İşletme Yapısı, Strateji ve Rekabet}

Anket çalışması sonucunda TR81 Düzey 2 Bölgesi mobilya ve kereste işletmelerinin işletme yapısı, strateji ve rekabet şartları illere ve sektöre göre Tablo 4'de gösterilmiştir.

Tablo 4: TR81 Düzey 2 Bölgesi Orman Endüstri İşletmelerinin strateji ve rekabet durumlarının koşulları.

\begin{tabular}{|c|c|c|c|c|c|c|}
\hline \multirow[t]{2}{*}{ İŞLETME STRATEJILERİ VE REKABET } & \multicolumn{2}{|c|}{ ZONGULDAK } & \multicolumn{2}{|c|}{ KARABÜK } & \multicolumn{2}{|c|}{ BARTIN } \\
\hline & MBLY & KRST & MBLY & KRST & MBLY & KRST \\
\hline $\begin{array}{l}\text { 34. Orman Ürünleri Endüstri işletmeleri arasında } \\
\text { yoğun bir rekabet vardır. }\end{array}$ & 2,80 & 3,40 & 3,50 & 3,57 & 3,33 & 3,86 \\
\hline $\begin{array}{l}\text { 35. Bölgedeki işletmelerin rekabetçi üstünlüğü, } \\
\text { düşük maliyetli ürünler üretmesinden } \\
\text { kaynaklanmaktadır. }\end{array}$ & 4,08 & 3,90 & 4,25 & 3,71 & 3,42 & 3,57 \\
\hline $\begin{array}{l}\text { 36. Bölgedeki işletmelerin rekabetçi üstünlüğü, } \\
\begin{array}{l}\text { yenilikçi } \\
\text { kaynaklanmaktadır. }\end{array}\end{array}$ & 2,72 & 2,10 & 2,75 & 2,14 & 2,92 & 2,57 \\
\hline $\begin{array}{l}\text { 37. Üretim sürecimizde ki makine alt yapımız yeterli } \\
\text { düzeydedir. }\end{array}$ & 3,68 & 3,80 & 3,50 & 2,86 & 3,83 & 3,71 \\
\hline $\begin{array}{l}\text { 38. Bölgedeki Orman Ürünleri Endüstri işletmeleri } \\
\text { üreticileri yeni çıkan teknolojiye adapte } \\
\text { olabilmektedir. }\end{array}$ & 2,76 & 2,90 & 1,75 & 2,00 & 2,50 & 2,86 \\
\hline $\begin{array}{l}\text { 39. Bölgedeki Orman Ürünleri Endüstri işletmeleri } \\
\text { alanında yenilikçi olabilmektedir. }\end{array}$ & 2,20 & 1,90 & 1,50 & 1,14 & 2,67 & 3,00 \\
\hline $\begin{array}{l}\text { 40. Bölgedeki Orman Ürünleri Endüstrindeki } \\
\text { işletmeler yereldeki üniversiteler ile Araştırma- } \\
\text { Geliştirme işbirliği yapmaktadır. }\end{array}$ & 1,20 & 1,10 & 1,00 & 1,00 & 2,00 & 2,14 \\
\hline $\begin{array}{l}\text { 41. İşletmemiz Araştırma-Geliştirme çalışmalarına } \\
\text { fon ayırmaktadır. }\end{array}$ & 1,80 & 1,30 & 1,50 & 1,86 & 2,33 & 2,29 \\
\hline $\begin{array}{l}\text { 42. İşletmemizin kendisine ait "patenti hakkı" } \\
\text { sağladığı ürünü vardır. }\end{array}$ & 1,40 & 1,00 & 1,00 & 1,00 & 1,67 & 1,71 \\
\hline $\begin{array}{l}\text { 43. İşletmemizin yönetim yapısı, akrabalık ve } \\
\text { arkadaşlık ilişkilerine göre yapılanmıştır. }\end{array}$ & 3,08 & 3,80 & 4,00 & 3,29 & 2,92 & 4,00 \\
\hline $\begin{array}{l}\text { 44. Bölgedeki Orman Ürünleri Endüstri işletmeleri } \\
\text { yeni ürünleri diğer işletmelerden taklit yoluyla } \\
\text { üretmektedir. }\end{array}$ & 4,32 & 4,50 & 4,25 & 4,32 & 4,50 & 4,25 \\
\hline
\end{tabular}

Tablo 4'e göre avantajlar:

- Orman Ürünleri Endüstri işletmeleri arasında yoğun bir rekabet olduğu, her üç ildeki kereste işletmeleri tarafından düşünülmektedir. Sadece Zonguldak mobilya işletmeleri 2.80 ortalama değer ile işletmeler arasında yoğun bir rekabet olduğu konusunda diğerleri kadar olumlu düşünmemektedir. 
- Üretim sürecinde ki makine alt yapılarının yeterli düzeyde olduğu, her üç ildeki mobilya işletmeleri tarafından düşünülmektedir. Sadece Karabük kereste işletmeleri 2,86'lık ortalama değer ile makine alt yapılarının yeterli olduğu konusunda diğerleri kadar olumlu düşünmemektedir.

Tablo 4'e göre dezavantajlar:

- Bölgedeki işletmelerin rekabetçi üstünlüğünün, düşük maliyetli ürünler üretmesinden kaynaklandığı, her üç ildeki mobilya ve kereste işletmeleri tarafindan düşünülmektedir. Zonguldak'ta yer alan mobilya işletmeleri 4.08, Karabük’te yer alan mobilya işletmeleri 4.25, Bartın'da yer alan mobilya işletmeleri 3.42 ortalama değere sahiptir. Zonguldak'ta yer alan kereste işletmeleri 3.90, Karabük'te yer alan kereste işletmeleri 3.71, Bartın'da yer alan kereste işletmeleri 3.57 ortalama değere sahiptir. Bölge işletmeleri yüksek bir ortalama değer ile bölgedeki rekabetçi üstünlüğün düşük maliyetli ürünlerden gerçekleştiğini düşünmektedir.

- Bölgedeki işletmelerin rekabetçi üstünlüğünün yenilikçi ürünler üretmesinden daha çok düşük maliyetli ürünler üretmesinden gerçekleştiği her üç ildeki mobilya ve kereste işletmeleri tarafindan düşünülmemektedir. Aynı zamanda bölge işletmeleri, ortalama 3 değerine sahip Bartın kereste işletmeleri dışında, bölge işletmelerinin yeterince yenilikçi olamadığını düşünmektedir.

- Bölgedeki Orman Ürünleri Endüstri işletmelerinin yeni ürünleri diğer işletmelerden taklit yoluyla üretmekte olduğu, her üç ildeki mobilya işletmeleri tarafından düşünülmektedir. Üstelik ortalama değerler çok yüksektir ve Zonguldak'ta yer alan mobilya işletmeleri 4.32, Karabük'te yer alan mobilya işletmeleri 4.25, Bartın'da yer alan mobilya işletmeleri 3.00 ortalama değere sahiptir. Zonguldak'ta yer alan kereste işletmeleri 4.50, Karabük'te yer alan kereste işletmeleri 3.86 ortalama değere sahiptir. Sadece Bartın kereste işletmeleri 2.86 ortalama değere sahiptir ve bu konuda diğerlerinden daha olumlu düşünmektedir.

- Bölgedeki Orman Ürünleri Endüstrindeki işletmelerinin yereldeki üniversiteler ile Araştırma-Geliştirme işbirliği yapmadığı, her üç ildeki mobilya ve kereste işletmeleri tarafından düşünülmektedir. Tablo 4 'teki patent konusundan sonra en düşük değerlerdir. Bölge işletmeleri konu hakkında oldukça olumsuz düşünmektedir.

- Her üç ildeki mobilya ve kereste işletmelerinin yeterince araştırma-geliştirme çalışmalarına fon ayırmadığı ve patent hakkı elde edemediği görülmüştür. İşletmelerin yönetim yapısının da akrabalık ve arkadaşlık ilişkilerine göre yapılandığı görülmektedir. Bölge işletmeleri içinde sadece Bartın mobilya işletmeleri 2,92'lik değer ile bu konuda daha biraz daha farklı düşünmektedir.

\section{SONUÇ VE ÖNERILER}

TR81 Düzey 2 Bölgesinde orman ürünleri endüstrisinin (mobilya ve kereste işletmeleri endüstrisi) rekabet gücü, Porter'ın Karo modeline göre sektörün avantaj ve dezavantajlarını belirlemesini amaçlayan anket çalışmasından elde edilen verilerle değerlendirilmiş ve verilen cevaplar çerçevesinde aşağıdaki sonuçlara ulaşılmıştır:

Faktör koşullarına göre:

- Bölgede yetişen hammadde kaynaklarına erişim ve çeşitliliği kereste işletmeleri açısından üç ilde de bir avantaj olarak görülmektedir. Her üç ilde ki kereste işletmeleri üretim için iklim şartlarını da uygun görmektedirler. Ancak Bölgede yetişen hammaddenin fiyatının uygun olmadığı çoğunluk kereste işletmeleri tarafından düşünülmektedir.

- Bölgedeki finans kurumlarının işletmelere yönelik çok sayıda finansal ürün ve hizmet yelpazesi sunabilmeleri üç ilde de hem mobilya hem de kereste işletmeleri için bir avantaj olarak görülmektedir. Diğer taraftan KOSGEB ve BAKKA destekli yapılar özel finans kurumlarından çok daha avantajlı alternatifler sunabilmektedir. Çok daha düşük faizler, birkaç y1l sonra başlayan ödemeler ve hibeler işletmelerin maliyetlerini önemli ölçüde düşürebilmekte, yeni firsatlar yakalanabilmekte, rekabet gücü gelişebilmektedir. Ancak TR81 mobilya ve kereste işletmeleri mevcut olanakları kullanamadığı ve konuyla ilgili yeterince farkındalığa sahip olmadığı görülmüştür.

- Bölgedeki karayollarının niteliğinin, üretim ve pazarlama ihtiyaçlarını karşılayacak standartlara sahip olmasını üç ilde de mobilya işletmeleri bir avantaj olarak görmektedir. Kereste de ise iki il avantaj olarak görmüş, bir ilin ise işletmelerinim ormanlık alanda, ulaşımı daha zor yerleşkelerde olmasından dolayı sorun yaşadığı görülmektedir. Bölgedeki liman alt yapısının, demir yolunun ve hava limanının üretim ve pazarlama ihtiyaçlarını karşılayacak standartlara yeterince sahip olmadığı ve geliştirilmesi 
gerektiği, her üç ildeki mobilya ve kereste işletmeleri tarafından da düşünülmektedir. Sonuç olarak sadece karayollarının etkin olmasına karşın bölgede farklı ulaşım alternatiflerinin olması bölge için olumludur. Özellikle liman alt yapısı ve demiryolu geliştirilebilir.

- Bölgedeki genel alt yapı olanaklarının (telefon, internet ve enerji) üretim ve pazarlama ihtiyaçlarını karşılayacak standartlara sahip olmasını üç ilde de mobilya işletmeleri bir avantaj olarak görmektedir. Kereste de ise bir il avantaj olarak görmekte, ancak iki il ise mevcut durumu yeterli görmemektedir. Özellikle Karabük/Yenice kereste işletmeleri haftada birkaç defa tekrarlayan elektrik kesintilerinden ve internet hatlarındaki sorunlardan bahsetmektedirler. Bölgede her il aynı olanaklara sahip değildir, özellikle kırsal ve orman alanları dezavantajlı bölgeler mevcuttur.

- İyi bir iş planı ile KOSGEB'den ve Kalkınma Ajansından destek almanın kolay olduğunu düşünen il ise sadece Bartın olmuştur. Bartın bölgesindeki kereste işletmelerinin daha yenilikçi ve gelişmeye istekli olduklarını söyleyebiliriz. Hatta bunlardan bir tanesi Efeler Kereste başka bir işletmenin kurulmasını teşvik etmiş̧ir. Bu işletmenin adı Ulusan Mobilyadır. Ulusan mobilya da "tonet" sandalye yapımında uzmanlaşmış, niş bir alana üretim yapmaktadır.

- Bölgedeki orman ürünleri endüstrisi işletmelerinin çalışanların mesleki gelişimi için eğitime yatırım yapmadığı, her üç ildeki mobilya ve kereste işletmeleri tarafından düşünülmektedir.

- Bölgedeki eğitim kurumlarının rekabetçi bir ekonominin gerekliliklerine cevap veremediği, her üç ildeki mobilya ve kereste işletmeleri tarafindan düşünülmektedir. İşletmeler ihtiyaç duyduğu yönetici ve mühendisleri ve vasıflı iş gücünü de bölgede bulamadığını söylemiştir. Bu olumsuzluklara rağmen bölgede orman fakültelerinin ve ilgili meslek yüksekokullarının varlığ́ gelişme potansiyeli için çok önemlidir. Ayrıca bölgede geçmişten gelen sektörel bilgi birimi mevcuttur ve eğitim kurumları bu bilgiye ulaşmalıdır.

- İş gücü maliyetlerinin bölge dışına göre daha düşük olmadığı, her üç ildeki mobilya ve kereste işletmeleri tarafından düşünülmektedir. Bölgede devlet sektörüne dayalı maden sektörü nedeniyle işgörenlerim Türkiye ortalamasının üstünde ücretlere alışkın olması ve birçok evde ya madende çalışan ya da emekli birinin olması insanları tembelliğe itmiş olduğu görülmektedir.

- Organize Sanayi bölgeleri ve Küçük Sanayi Siteleri gibi fiziksel altyapıların yeterli olmadığg, her üç ildeki mobilya ve kereste işletmeleri tarafından düşünülmektedir.

Talep koşullarına göre:

- Her üç ilde ki mobilya işletmeleri "bölgedeki işletmelerin devamlılığını sağlayacak iç talebin ve bölge dışından talebin mevcut olduğunu" düşünmektedir. Kereste işletmelerine iç talepten daha çok dış talep geldiği ve bu işletmelerin devamlılığında, dış talebin mobilyaya göre daha yüksek olduğu görülmüştür.

- Her üç ilde ki mobilya işletmeleri "işletmeleri açısından tüketicilerin beklentilerinin, yeni ürünler geliştirilmesi üzerinde etkili olduğunu” düşünmektedir. Kereste işletmelerinde ise Zonguldak ve Karabük'ün bu konuda olumlu düşünmemektedir. Ancak "iyi bir iş planı ile KOSGEB'den ve Kalkınma Ajansından destek almanın kolay olduğunu” düşünmesinde de olduğu gibi, Bartın kereste işletmeleri bu konuda, diğerlerinden farklı olarak olumlu düşünmüştür.

- Her üç ilde ki mobilya ve kereste işletmeleri, bölgedeki tüketicilerin ürünlerin alımı ile ilgili kararlarında en önemli etkenin "hem ürünün düşük fiyatta olması hem de ürünün nitelikli olması" olduğunu ifade etmiştir. Her ikisinin de tüketici için önemli olduğunu düşünmektedirler. Sonuç olarak ürün için kalitenin düşük fiyatla sunulması gerekliliğinin farkında olunduğunu görüyoruz. Ancak yüz yüze yapılan anket mülakatlarında bu farkındalığga rağmen çok azının bunu gerçekleştirebildiği görülmüştür. Nitekim "işletme stratejileri ve rekabet" bölümümdeki anket sorularında yenilikçiliğe ve yeni ürünlerdeki taklitçiliğe verilen cevaplar bu sonucu destekler niteliktedir. Farkındalığın olması olumlu, yeterince gerçekleştirilememesi ise olumsuz olarak değerlendirilebilir.

- Bölgede ki işletmelerinin çoğunluğu, işletmelerinin ağırlıklı olarak iç pazara yönelik üretim yaptığını, ihracatı ihmal ettiğin düşünmektedir. TR81 bölgesi ağaç-orman ürünleri sektörü dış ticaret hacmi çok düşüktür ve ihracat ithalatı karşılayamamaktadır. Bölge sektörü ağırlıklı olarak başta inşaat sektörü olmak üzere yurt içi ihtiyaçları karşılamakta ve katma değeri yüksek ürünler imal edememektedir. Mobilya sektöründe ise ihracat ithalatı karşılamakla beraber dış ticaret hacmi çok düşüktür.

İlgili ve destekleyici kuruluşlara göre:

- İşletmelerin üretimine dönük çok sayıda tedarikçi olduğu, her üç ildeki mobilya ve kereste işletmeleri tarafından düşünülmektedir. Özellikle kereste işletmelerinin bu konuda oranı daha fazladır ve oldukça yüksektir. Bölgedeki işletmelerin bu konuda olumlu düşündüğü ve bu durumun bölge için bir avantaj olduğu görülmektedir. Ayrıca bölgedeki mobilya ve kereste işletmeleri çok sayıda tedarikçi olduğunu, kaliteli hizmet verdiklerini düşünseler de bu işletmelerin onların rekabet gücünün artmasına etkisini yeterli bulmadıklarını ifade etmişlerdir. Sonuç olarak mobilya işletmeleri açısında bölgede ki tedarikçi 
firmalarının bölge dışındaki firmalar düzeyinde olmadığı, kendilerini geliştirmeleri gerektiğgi görülmektedir.

- Ticaret ve Sanayi Odaları, Meslek Odaları gibi kuruluşların çalışmalarının işletmelerinin gelişmesine ve sektördeki ilişkilerin artmasına katkıda bulunduğunu, sadece Bartın mobilya ve kereste işletmeleri düşünmektedir. Aynı şekilde bölgedeki KOSGEB ve Kalkınma Ajansının çalışmalarının işletmelerin rekabet gücünün artmasına katkıda bulunduğunu da, sadece Bartın mobilya ve kereste işletmeleri düşünmektedir.

- Yereldeki Orman Fakülteleri ile olan ilişkilerin, üretim süreçleri ve pazarlama stratejileri üzerinde etkili olmadığı, her üç ildeki mobilya ve kereste işletmeleri tarafından düşünülmektedir.

- Sektördeki işletmelerin tanıtım, pazarlama, nakliye ve AR_GE gibi alanlarda işbirliği yapmadığı, her üç ildeki mobilya ve kereste işletmeleri tarafindan düşünülmektedir.

- Her üç ildeki mobilya ve kereste işletmelerinin, ürünlerin dağıtım ve pazarlamasında yerel şirketleri kullanmadığı ve birçoğunun kendi araçlarının olduğu görülmüştür. İşletmelere dışarıdan sağlanan lojistik ancak orta büyüklükteki işletmeler tarafından tercih edilmektedir.

- Bölgede ağaç atıklarını kullanan fabrikaların mevcut olmadığı, her üç ildeki mobilya ve kereste işletmeleri tarafından düşünülmektedir. Ancak Resan Vadi isimli bir işletme ağaç atıklarını kullanarak yakıt için ürün üretmeye başlamıştır. Ancak henüz çevresindeki işletmelerle yeterli ilişkiyi kuramamıştır.

İşletme yapısı, strateji ve rekabet koşullarına göre:

- Bölge işletmeleri arasında yoğun bir rekabet olduğu, her üç ildeki kereste işletmeleri tarafindan düşünülmektedir. Mobilya sektöründe ise Karabük ve Bartın işletmeleri yoğun rekabetin olduğunu, Zonguldak işletmeleri ise yoğun rekabetin olmadığını düşünmektedir.

- Bölgedeki orman ürünleri endüstri işletmelerin rekabetçi üstünlüğ̈nün, düşük maliyetli ürünler üretmesinden kaynaklandığı, her üç ildeki mobilya ve kereste işletmeleri tarafından düşünülmektedir. Aynı zamanda bölge işletmeleri, Bartın kereste işletmeleri dışında, bölge işletmelerinin yeterince yenilikçi olamadığını düşünmektedir.

- Bölgedeki orman ürünleri endüstri işletmelerinin yeni ürünleri diğer işletmelerden taklit yoluyla üretmekte olduğu, her üç ildeki mobilya işletmeleri tarafından düşünülmektedir. Sadece Bartın kereste işletmeleri bu konuda diğerlerinden daha olumlu düşünmektedir.

- Üretim sürecinde ki makine alt yapılarının yeterli düzeyde olduğu, her üç ildeki mobilya işletmeleri tarafından düşünülmektedir. Kereste işletmelerinde ise Zonguldak ve Bartın makine alt yapılarının yeterli düzeyde olduğunu, Karabük ise makine alt yapılarının yeterli olmadığını düşünmemektedir. Genel olarak makine alt yapılarının yeterli düzeyde olduğu düşünülmektedir.

- Bölgedeki orman ürünleri endüstri işletme üreticilerinin yeni çıkan teknolojiye yeterince adapte olamadığı, her üç ildeki mobilya ve kereste işletmeleri tarafindan düşünülmektedir. Bölge işletmelerinin makine alt yapılarının yeterli olduğunu düşünmesi, bunun yanında teknolojiye yeterince adapte olamadığını düşünmesi uzman işgücü eksikliğinden kaynaklanıyor ve mevcut teknoloji etkin kullanılamıyor olabilir.

- Bölgedeki orman ürünleri endüstrindeki işletmelerinin yereldeki üniversiteler ile Araştırma-Geliştirme işbirliği yapmadığı, her üç ildeki mobilya ve kereste işletmeleri tarafindan düşünülmektedir. Bölge işletmelerinin bu konu hakkında oldukça olumsuz düşündüğü görülmektedir.

- Her üç ildeki mobilya ve kereste işletmeleri tarafından, işletmelerin araştırma-geliştirme çalışmalarına fon ayırmadığı görülmektedir. Bölge işletmelerinin patent konusunda durumları oldukça olumsuzdur.

- İşletmelerin yönetim yapısının da akrabalık ve arkadaşlık ilişkilerine göre yapılandığı görülmektedir.

Çalışmada ulaşılan sonuç dezavantajların avantajlardan fazla olması nedeniyle sektörün rekabet gücünün düşük olduğudur. Bu nedenle karo modelindeki unsurlar arasında, henüz yeterince gelişmemiş karşlıklı bağlılık ilişkileri rekabeti geliştirememiş̧ir. Ancak faktör koşullarında hammadde faktörü, talep koşullarında iç ve dış talebin mevcut olması, ilgili ve destekleyici kuruluşlarda çok sayıda ve nitelikli hizmet verebilen tedarikçilerin olması ve rekabet koşullarında makine alt yapısının yeterli olması önemli avantajlardır. Dezavantajlar ise bölgedeki aktörlerin doğru yönetimiyle ve karşlıklı ilişkilerinin sağlanmasıyla olumluya dönüştürülebilecek özelliktedir. Avantajı olunan konuları daha da geliştirerek, dezavantajı konuları da doğru yöneterek TR81 Düzey 2 Bölgesi orman ürünleri endüstrisinin (mobilya ve kereste sektörü) rekabet gücü arttırılabilir. Önemli olan koşulların birbirini nasıl etkilediğinin farkında olarak, avantaj ve dezavantajlara odaklanmak ve süreci doğru stratejilerle yönetebilmektir. TR81 bölgesinde mobilya ve kereste sektörü için, sürecin doğru yönetilmesinde etkili olabilecek bir girişim ya da yönetim grubun önerilebilir. 


\section{TEŞEKKÜR}

Gerçekleştirilen bu çalışma Bartın Üniversitesi Bilimsel Araştırma Projeleri Komisyonu tarafından desteklenmiştir (Proje No: 2013-1-75). Bartın Üniversitesi Bilimsel Araştırma Projeleri Komisyonuna teşekkürlerimizi sunarız.

\section{KAYNAKLAR}

○ Alsaç, F. 2010. Bölgesel Gelişme Aracı Olarak Kümelenme Yaklaşımı ve Türkiye için Kümelenme Destek Modeli Önerisi. Planlama Uzmanlığı Tezi (yayımlanmamış), Devlet Planlama Teşkilatı Uzmanlık Tezleri, Ankara, $176 \mathrm{~s}$.

- Arıç, H. 2011. Ulusal ve Uluslararası Rekabetin Geliştirilmesinde Kümelenme Politikası: Kayseri Mobilya Sektöründe Bir Uygulama. Doktora Tezi (yayımlanmamış), T.C. Erciyes Üniversitesi Sosyal Bilimler Enstitüsü, İktisadi Gelişme Ve Uluslararası İktisat Bilim Dalı, Kayseri, $226 \mathrm{~s}$.

- BAKKA, 2015. Bülten, ISSN: 2148-3035, Y. 2, 84s.

○ BAKKA, 2014. 2015-2025 Bölgesel İnovasyon Stratejisi ve Eylem Planı, Batı Karadeniz Kalkınma Ajans1,4-10.

- BAKKA, 2013a. 2014-2023 Bat Karadeniz Bölge Planı, Cilt 1, Batı Karadeniz Kalkınma Ajansı, 15-63.

- BAKKA, 2013b. 2014-2023 Bat Karadeniz Bölge Plan1, Cilt 2, Batı Karadeniz Kalkınma Ajans1, 4-25.

○ Bulu, M, Eraslan, İ. H. ve Şahin, Ö. 2004. Elmas Modeli İle Ankara Bilişim Kümelenmesi Rekabet Analizi. 3.Ulusal Bilgi, Ekonomi ve Yönetim Kongresi, 25-26 Kasım, Osmangazi Üniversitesi, Eskişekir, 143-153.

○ Cansız, M. 2011. Türkiye Kümelenme Politikaları ve Uygulama,1. Basım, Organize Sanayi Bölgeleri Üst Kurulu Yayınları, Ankara, 156 s.

○ Çivi, E. 2001. Rekabet Gücü: Literatür Araştırması, Celal Bayar Üniversitesi SBE İşletme ABD Yönetim ve Ekonomi Dergisi, Cilt: 8, Sayı: 2, Manisa, 21-38.

- Keskin, H. 2009. Kümelenme ve Sektörel Bağlantıları Açısından Isparta İli Orman Ürünleri Endüstrisinin Değerlendirilmesi, Doktora Tezi (yayımlanmamış), Süleyman Demirel Üniversitesi Sosyal Bilimler Enstitüsü, İktisat Anabilim Dalı, Isparta, 460s.

- McFetridge, D. G. 1995. Competitiveness: Concepts and Measures. Industry Canada Occasional Paper, Number 5, April, pp. 1-44.

○ Porter, M. E. 2010. Rekabet Stratejisi: Sektör ve Rakip Analiz Teknikleri. Çev. Gülen Ulubilgen, Sistem Yayıncılık, İstanbul, $493 \mathrm{~s}$.

- Porter, M. E. 1998. The Competitive Advantage of Nations, On Competition, Harvard Business School Publishing Corporation, Porter M (ed.), Boston, 171-211.

- Porter, M. E. 1990. The Competitive Advantage of Nations. Free Pres, New York, 854 s.

- Sarıdoğan, E. 2010. Mikroekonomi ve Makroekonomi Düzeyinde Küresel Rekabet Gücünü Etkileyen Faktörler. 1. Basım, İTO Yayınları, Yayın No: 2010-51, İstanbul, 397 s.

- T.C. Kalkınma Bakanlığı, 2013. Onuncu Kalkınma Planı 2014-2018, Devlet Planlama Teşkilatı, Ankara.

○ T. C. Kalkınma Bakanlığı. (2013). Bölgesel Gelişme Ulusal Stratejisi. Ankara: Kalkınma Bakanlığı.

○ URAK 2011. İllerarası Rekabetçilik Endeksi 2009-2010, Uluslararası Rekabet Araştırmaları Kurumu, İstanbul, $228 \mathrm{~s}$.

○ WEF 2014. The Global Competitiveness Report 2014-2015, World Economic Forum, Geneva, 565 S.

○ URL-1 2016 http://www. rekabetdernegi.org / rekabethakkinda.htm\#rekabet (12.10.2016). 